\title{
Relation between Vitamin D Level and Knowledge and Attitude Towards Sunlight Exposure among Asthma Outpatients in Surabaya
}

\author{
Amelia Lorensia, ${ }^{1}$ Rivan Virlando Suryadinata, ${ }^{2}$ Gebriella Ayuni Amir ${ }^{3}$ \\ ${ }^{1}$ Department of Clinical-Community Pharmacy, Faculty of Pharmacy, Universitas Surabaya, Surabaya, Indonesia, \\ ${ }^{2}$ Department of Public Health, Faculty of Medicine, Universitas Surabaya, Surabaya, Indonesia, \\ ${ }^{3}$ Pharmacist Study Program, Faculty of Pharmacy, Universitas Surabaya, Surabaya, Indonesia
}

\begin{abstract}
Asthma has become one of the health problems in the world. Asthma is characterized by chronic inflammation of the respiratory tract which leads to breathlessness, wheezing, and airflow limitation. Inflammatory reaction in asthma is related to inadequate vitamin $\mathrm{D}$ level. Vitamin $\mathrm{D}$ is a vitamin produced naturally by the body when exposed to sunlight that has immunomodulatory properties can reduce inflammation. Knowledge and positive attitude to sun exposure are necessary to prevent severe asthma attacks. This was a cross-sectional study involving 26 subjects in a private university in East Surabaya during January-June 2017 that was aimed to determine the relation between vitamin D and knowledge and attitude towards sunlight exposure. Data were collected by measuring the vitamin D level in blood serum and through the use of a questionnaire that consisted of two aspects, level of knowledge and attitude to sun exposure. Chi-square test was used to analyze the relationship between vitamin D level, knowledge, and attitude. No relationship was found between blood vitamin D level of asthma respondents and level of knowledge of sun exposure related to vitamin $\mathrm{D}(\mathrm{p}=0.444, \mathrm{p}>0.05)$. The same was also true for the relationship between blood vitamin $\mathrm{D}$ level of asthma respondents and attitude to sun exposure related to vitamin $\mathrm{D}(\mathrm{p}=0.768, \mathrm{p}>0.05)$. The closeness of the relationship between knolwedge and attitude was also relatively low (0.093). In conclusion, there is no correlation between vitamin $\mathrm{D}$ level, knowledge, and attitude. In addition, there is also no correlation between knowledge and attitude with low relationship between the two variables.
\end{abstract}

Key words: Asthma, attitude, knowledge, sun exposure, vitamin D level

\section{Hubungan Kadar Vitamin D dengan Pengetahuan dan Sikap tentang Paparan Sinar Matahari pada Pasien Asma Rawat Jalan di Surabaya}

\begin{abstract}
Abstrak
Asma telah menjadi masalah kesehatan di dunia. Asma ditandai oleh peradangan kronis pada saluran pernapasan yang menyebabkan sesak napas, mengi, dan keterbatasan aliran udara. Reaksi peradangan pada asma terkait dengan kadar vitamin D yang tidak memadai. Vitamin D merupakan vitamin yang diproduksi secara alami oleh tubuh ketika terkena sinar matahari yang memiliki sifat imunomodulator dapat mengurangi peradangan. Pengetahuan dan sikap positif terhadap paparan sinar matahari diperlukan untuk mencegah risiko keparahan asma. Penelitian ini menggunakan metode cross-sectional yang melibatkan 26 subjek di sebuah universitas swasta di Surabaya Timur pada Januari-Juni 2017 yang bertujuan menentukan hubungan vitamin D dengan pengetahuan dan sikap terhadap paparan sinar matahari. Data dikumpulkan dengan mengukur kadar vitamin D dalam serum darah dan melalui penggunaan kuesioner yang terdiri atas dua aspek, tingkat pengetahuan dan sikap terhadap paparan sinar matahari. Uji chi-square digunakan untuk menganalisis hubungan antara kadar vitamin D, pengetahuan, dan sikap. Tidak ada hubungan yang ditemukan antara kadar vitamin D darah responden asma dan tingkat pengetahuan paparan sinar matahari yang terkait dengan vitamin $\mathrm{D}(\mathrm{p}=0,444 ; \mathrm{p}>0,05)$. Hal yang sama juga berlaku untuk hubungan antara kadar vitamin D darah responden asma dan sikap terhadap paparan sinar matahari yang terkait dengan vitamin $\mathrm{D}(\mathrm{p}=0,768 ; \mathrm{p}>0,05)$. Kedekatan hubungan antara pengetahuan dan sikap juga relatif rendah (o,093). Simpulan, tidak ada hubungan antara kadar vitamin D, pengetahuan, dan sikap. Selain itu, juga tidak ada hubungan yang rendah antara pengetahuan dan sikap.
\end{abstract}

Kata kunci: Asma, kadar vitamin D, paparan sinar matahari, pengetahuan, sikap

Received: 30 September 2017; Revised: 30 July 2019; Accepted: 31 July 2019; Published: 31 December 2019

Correspondence: Dr. Amelia Lorensia, S.Farm., M.Farm.Klin., Apt. Department of Clinical-Community Pharmacy, Faculty of Pharmacy, Universitas Surabaya. Jln. Raya Kalirungkut, Surabaya 60293, East Java, Indonesia. E-mail: amelia.lorensia@gmail.com 


\section{Introduction}

Asthma has become a significant health problem in the world. It is estimated that the global prevalence for asthma has reached 235 million people and 24 thousands died because of this disease. ${ }^{1}$ Asthma is characterized by chronic inflammation of respiratory tract with the symptoms of shortness of breath, wheezing, chest pressure, heavy coughing which constantly gets worse, and airflow limitation. This disease can specifically create burdens for the patient, and the family and society in general, because it decreases productivity. ${ }^{2}$

One of the factors affecting the high incidence of asthma is the level of vitamin D in the body. This is due to the fact that low vitamin $\mathrm{D}$ level in the body can trigger asthma attacks. ${ }^{3}$ A previous study by Shebl et al. ${ }^{4}$ stated that asthma patients generally have a low level of vitamin $\mathrm{D}$ in their body. Vitamin D has a strong relationship with inflammation reaction in asthma that vitamin D deficiency may worsen the disease. ${ }^{5}$ According to a systematic review by Bozzetto et al. ${ }^{6}$ vitamin $\mathrm{D}$ has been proven to have an immunomodulator nature by stimulating the immune system to prevent the production of cytokine in order to reduce inflammation. Vitamin D is considered to be a strong predictor of asthma. Increasing vitamin $\mathrm{D}$ level will reduce the exacerbation of asthma and may become the primary prevention of asthma. ${ }^{7}$

Vitamin D is the only vitamin that is naturally produced by the body when it is exposed to sunlight. In a study in England, around $72 \%$ of the participants know about vitamin D from television, internet, radio, newspaper, family, and friends. ${ }^{8}$ Based on a study conducted by Arora et al. ${ }^{9}$ to 599 participants in India on the level of knowledge and attitude towards sunlight exposure, almost all participants (99.5\%) have heard about vitamin D and $53.3 \%$ of them know that sunlight is the primary source of vitamin D. Despite the knowledge on the main source of vitamin D, 385 participants (64.2\%) do not like to be exposed to sunlight and almost half of the participants (49.7\%) thought that sunlight is dangerous for their skin, and around $43 \%$ participants use umbrellas to protect them from sunlight.

Knowledge and attitude towards sunlight are essential because sunlight has a significant benefit in preventing vitamin $\mathrm{D}$ deficiency. ${ }^{10}$ The level of knowledge and attitude towards exposure to sunlight can be measured using a questionnaire, which has been done by Arora et al., ${ }^{9}$ Zhou et al., ${ }^{11}$ and Bathi et al. ${ }^{12}$ The purpose of this study was to identify relationship between the level of vitamin D and the level of knowledge and attitude towards the exposure to sunlight in its role as an important component of vitamin D formation among asthma patients.

\section{Methods}

This was a cross-sectional study on asthma patients, or respondents, where respondents were given a questionnaire to measure the level of knowledge and attitude towards sunlight exposure and had their blood vitamin D level measured. Sampling were carried out in a private university in Rungkut district, East Surabaya, Surabaya, East Java during January-June 2017 and analysis of vitamin D level was carried out at the Biochemistry Laboratory of Universitas Airlangga, Surabaya, East Java.

Variables in this study were vitamin D level and level of knowledge and attitude towards sunlight exposure related to the production of vitamin D. Measurement of vitamin D level in this study was performed by measuring serum vitamin D level [25(OH)D]. Knowledge was defined as the knowledge possessed by respondents on sunlight exposure as the primary source of vitamin $\mathrm{D}$. The attitude was defined as the daily attitude towards sunlight exposure. Data collection for knowledge and attitude variables was performed using questionnaire from previous studies by Arora et al., ${ }^{9}$ Zhou et al., ${ }^{11}$ and Bathi et al. ${ }^{12}$

The population of this study was adult asthma patients ( $\geq 18$ years) in the university. Samples (respondents) were those who met the inclusion and exclusion criteria. The inclusion criteria used in this study was willing to volunteer to participate in the study and signed a written informed consent form. Meanwhile, the exclusion criteria were: (1) other breathing-related diseases, (2) chronic and liver-kidney disorders, (3) smoking, (4) consumption of drugs that can affect vitamin D level. Purposive sampling method was used to obtain respondents using the following formula.

$\mathrm{n}=\frac{\mathrm{Z}^{2} \cdot \mathrm{P} \cdot \mathrm{Q}}{\mathrm{d}^{2}}$

Description: $\mathrm{n}=$ sample size; $\mathrm{Z}=$ normal standard deviation, in which the value depends on the $p$ value from distribution table $\mathrm{Z}=1.96 ; \mathrm{P}=$ proportion for certain properties estimated to occur in the population (East 
Java $)=0.017 ; \mathrm{Q}=1.0-\mathrm{P}(\mathrm{Q}$ is the proportion of properties that are not expected to occur in the population $)=1-0.017=$ 0.983; $\mathrm{D}=$ degree of deviation $=0.05$

Hence, the minimum sample size (n) for each group was $25.67 \approx 26$ people.

Two types of validation were conducted for the questionnaire, which was taken from other studies. The first validation was the internal validation where the questionnaire was translated into Indonesian and then validated by a peer group. The second validation was the external validation which was performed by trying out the questionnaire to 30 respondents to be filled and the results were analyzed using the SPSS software program. Reliability test was then carried out on a validated questionnaire using Cronbach's alpha method in SPSS software.

Measurement of 25-OH vitamin D level using blood serum. Blood sampling was performed by a health care worker drawing $3 \mathrm{~mL}$ venous blood. Blood sample was then kept in a vacutainer tube and centrifucation was done to get the serum. Serum was placed in an Eppendorf tube and transported to the Biochemical Laboratory of Universitas Airlangga for vitamin D level analysis. Ethical clearance for this study was obtained from the Institutional Ethical Committee, University of Surabaya with the issuance of an Ethical Clearance Certificate number: 021/KE/I/2017. Analysis of the results was performed using various tests as listed in Table 1.

\section{Results}

Female comprised the majority of the respondents and most of the respondents were in the age group of 20-22 years old with the range of 17 to 25 years old. Details on the demographics of respondents are shown in Table 2.

For knowledge aspect of the questionnaire, the validity and reliability tests revealed that each item in the knowledge section of the questionnaire was valid (r-count>0.361) and reliable (Cronbach's alpha $=0.709$ ) (Table 3 ). Furthermore, the validity and reliability tests for attitude aspect of the questionnaire also showed that each item was valid (r-count>0.361 and realiable (Cronbach's alpha $=0.704$ (Table 4).

The vitamin $\mathrm{D}$ level was divided into 3 categories: deficient $(<20 \mathrm{ng} / \mathrm{mL} ;<50 \mathrm{nmol} / \mathrm{L})$; insufficient (20-32 ng/mL; $50-80 \mathrm{nmol} / \mathrm{L}$ ), and normal (54-90 ng/mL; $135-225 \mathrm{nmol} / \mathrm{L}){ }^{13}$ None of the respondents achieved the normal level of vitamin D, with 24 respondent experienced vitamin D insufficiency and 2 had vitamin D deficiency.

Level of knowledge was determined from the total score of individual item scores. Each correct response was scored 1 . It was revealed that 19 of 26 of respondents had excellent knowledge ( $\geq 6$ points) on sunlight exposure in relation to vitamin $\mathrm{D}$ and 7 of 26 respondents had low knowledge $(<6$ points) on sunlight exposure in relation to vitamin $\mathrm{D}$ (Table 5).

Of all respondents with vitamin D insufficiency, 18 had excellent knowledge of sunlight exposure in vitamin $\mathrm{D}$ production while 6 had low knowledge. Of the 2 respondents with vitamin D deficiency, 1 had excellent knowledge and 1 had low knowledge. Analysis using with the chi-square method showed a p value of 0.444 (p value>0.05); hence, no significant relationship was found between respondent's vitamin D level and level of knowledge regarding sunlight exposure related to vitamin D.

For the attitude aspect, 1 of 26 respondents

Table 1 Data Analysis

\begin{tabular}{|c|c|c|c|}
\hline Purpose & Variables & $\begin{array}{c}\text { Data Type } \\
\text { (Scale) }\end{array}$ & Data Analysis \\
\hline $\begin{array}{l}\text { To identify relationship between vitamin D level } \\
\text { and the level of knowledge towards sunlight } \\
\text { exposure in asthma respondents }\end{array}$ & $\begin{array}{l}\text { Vitamin D level } \\
\text { Knowledge on sunlight } \\
\text { exposure }\end{array}$ & $\begin{array}{l}\text { Ordinal } \\
\text { Nominal }\end{array}$ & Chi-square \\
\hline $\begin{array}{l}\text { To identify relationship between vitamin D level } \\
\text { and the attitude of asthma respondents to sunlight } \\
\text { exposure }\end{array}$ & $\begin{array}{l}\text { Vitamin D level } \\
\text { Attitude towards } \\
\text { sunlight exposure }\end{array}$ & $\begin{array}{l}\text { Ordinal } \\
\text { Nominal }\end{array}$ & Chi-square \\
\hline $\begin{array}{l}\text { To identify relationship between the level of } \\
\text { knowledge and attitude towards sunlight exposure }\end{array}$ & $\begin{array}{l}\text { Knowledge on sunlight } \\
\text { exposure } \\
\text { Attitude towards }\end{array}$ & $\begin{array}{l}\text { Nominal } \\
\text { Nominal }\end{array}$ & $\begin{array}{l}\text { Contingency } \\
\text { coefficient }\end{array}$ \\
\hline
\end{tabular}




\begin{tabular}{|c|c|}
\hline Characteristics & Frequency \\
\hline \multicolumn{2}{|l|}{ Gender } \\
\hline Male & 7 \\
\hline Female & 19 \\
\hline \multicolumn{2}{|l|}{ Age (years) } \\
\hline $17-19$ & 7 \\
\hline $20-22$ & 15 \\
\hline $23-25$ & 4 \\
\hline \multicolumn{2}{|l|}{ History of asthma treatment } \\
\hline Oral short-acting $\beta-2$ agonist & 7 \\
\hline Inhaled short-acting $\beta-2$ agonist & 19 \\
\hline
\end{tabular}

had a right attitude ( $\leq 9$ points) to sunlight exposure related to vitamin D and 25 of 26 had a bad attitude ( $>9$ points).

Among those with vitamin D insufficiency, 23 respondents had bad attitude towards sunlight exposure and one had the right attitude towards sunlight exposure. No respondent with vitamin D deficiency had the right attitude towards sunlight exposure (Table 6).

Chi-square test revealed a $\mathrm{p}$ value of 0.768 (p value>0.05), showing that there was no significant relationship between vitamin D level and with attitude towards sunlight exposure.

Analysis on the relationship between knowledge and attitude showed that 19 of 26 respondents had excellent knowledge but bad attitude towards sunlight exposure. None has good knowledge and attitude towards sunlight exposure. The approximate significance table presented a value of 0.093 , showing low relationship between knowledge and attitude.

\section{Discussion}

More female involved as the respondents in this study. This might be due to the current prevalence of asthma that is higher in females. High levels of estrogen in women can inhibit the body's immune response to allergic reactions that may cause adverse effects on asthma. Estrogen also acts as a proinflammatory substance that can trigger inflammation, especially through its influence on mast cells to release histamine and other inflammatory mediators. ${ }^{14}$ Based on a study conducted by Lee et al., ${ }^{15}$ women have better knowledge about sun protection when compared to men that they tend to use sunscreens more often to protect the skin from sun exposure than men.

Age can affect vitamin D level in the body

\section{Table 3 Validity Test Results for Knowledge Items}

\begin{tabular}{|c|c|c|}
\hline \multicolumn{2}{|c|}{ Items } & \multirow{2}{*}{$\begin{array}{c}\begin{array}{c}\text { Corrected Item- } \\
\text { Total Correlation }\end{array} \\
0.590\end{array}$} \\
\hline 1 & $\begin{array}{l}\text { a. Are you familiar with vitamin } \mathrm{D} \text { ? } \\
\text { b. In your opinion, what is vitamin } \mathrm{D} \text { ? }\end{array}$ & \\
\hline 2 & Where did you learn about vitamin $\mathrm{D}$ ? & 0.552 \\
\hline 3 & $\begin{array}{l}\text { a. What is the greatest source of vitamin } \mathrm{D} \text { ? } \\
\text { b. Other than the greatest source, mention other sources of vitamin } \mathrm{D} \text { ! }\end{array}$ & 0.487 \\
\hline 4 & What is the benefit of vitamin D for your body? & 0.517 \\
\hline 5 & What is the effect of vitamin D deficiency? & 0.464 \\
\hline 6 & Which of the followings can cause your body to be vitamin D deficient? & 0.431 \\
\hline 7 & $\begin{array}{l}\text { a. Do you think sunlight help produce vitamin D? } \\
\text { b. Why? }\end{array}$ & 0.362 \\
\hline 8 & $\begin{array}{l}\text { a. Is exposure to sunlight dangerous to your skin? } \\
\text { b. Why? }\end{array}$ & 0.433 \\
\hline 9 & $\begin{array}{l}\text { In your opinion, the best time for the body to be exposed directly under sunlight } \\
\text { is at ............ a.m./p.m. to ........... a.m./p.m. so that the body can obtain vitamin } \\
\text { D. }\end{array}$ & 0.413 \\
\hline 10 & $\begin{array}{l}\text { How long does the body need to be exposed to direct sunlight in order to obtain } \\
\text { vitamin D? }\end{array}$ & 0.487 \\
\hline 11 & What is the sun protection factor (SPF) number which is best for your body? & 0.556 \\
\hline
\end{tabular}


Table 4 Validity Test Results for Attitude Items

\begin{tabular}{|c|c|c|}
\hline \multicolumn{2}{|c|}{ Items } & \multirow{2}{*}{$\begin{array}{c}\text { Corrected Item- } \\
\text { Total Correlation } \\
0.477\end{array}$} \\
\hline 1 & Do you often travel or do outdoor activities under direct sunlight? & \\
\hline 2 & How long in a day are you exposed to direct sunlight? & 0.418 \\
\hline & $\begin{array}{l}\text { a. Do you avoid exposure to direct sunlight? } \\
\text { b. Why do you avoid or not avoid exposure to direct sunlight? }\end{array}$ & 0.587 \\
\hline 4 & $\begin{array}{l}\text { a. Do you use skin protection products (umbrella, hat, jacket, sunblock cream, } \\
\text { etc.) when you are exposed to direct sunlight? } \\
\text { b. What kind of skin protector do you use? }\end{array}$ & 0.366 \\
\hline 5 & Why do you choose the skin protector? & 0.621 \\
\hline 6 & $\begin{array}{l}\text { a. Do you consume vitamin D supplements? } \\
\text { b. What supplements do you consume? } \\
\text { c. Why do you consume the supplements? }\end{array}$ & 0.458 \\
\hline 7 & What is your purpose in consuming vitamin D supplements? & 0.443 \\
\hline & $\begin{array}{l}\text { a. Do you think the vitamin D level in your body is sufficient/enough? } \\
\text { b. Why? }\end{array}$ & 0.433 \\
\hline & $\begin{array}{l}\text { a. Are you interested in knowing more about vitamin D? } \\
\text { b. Why? }\end{array}$ & 0.598 \\
\hline
\end{tabular}

Note: $r_{\text {table }}$ value was 0.361. Declared as valid if $r_{\text {count }}>r_{\text {table }}$

Table 5 Item Responses in Knowledge Aspect

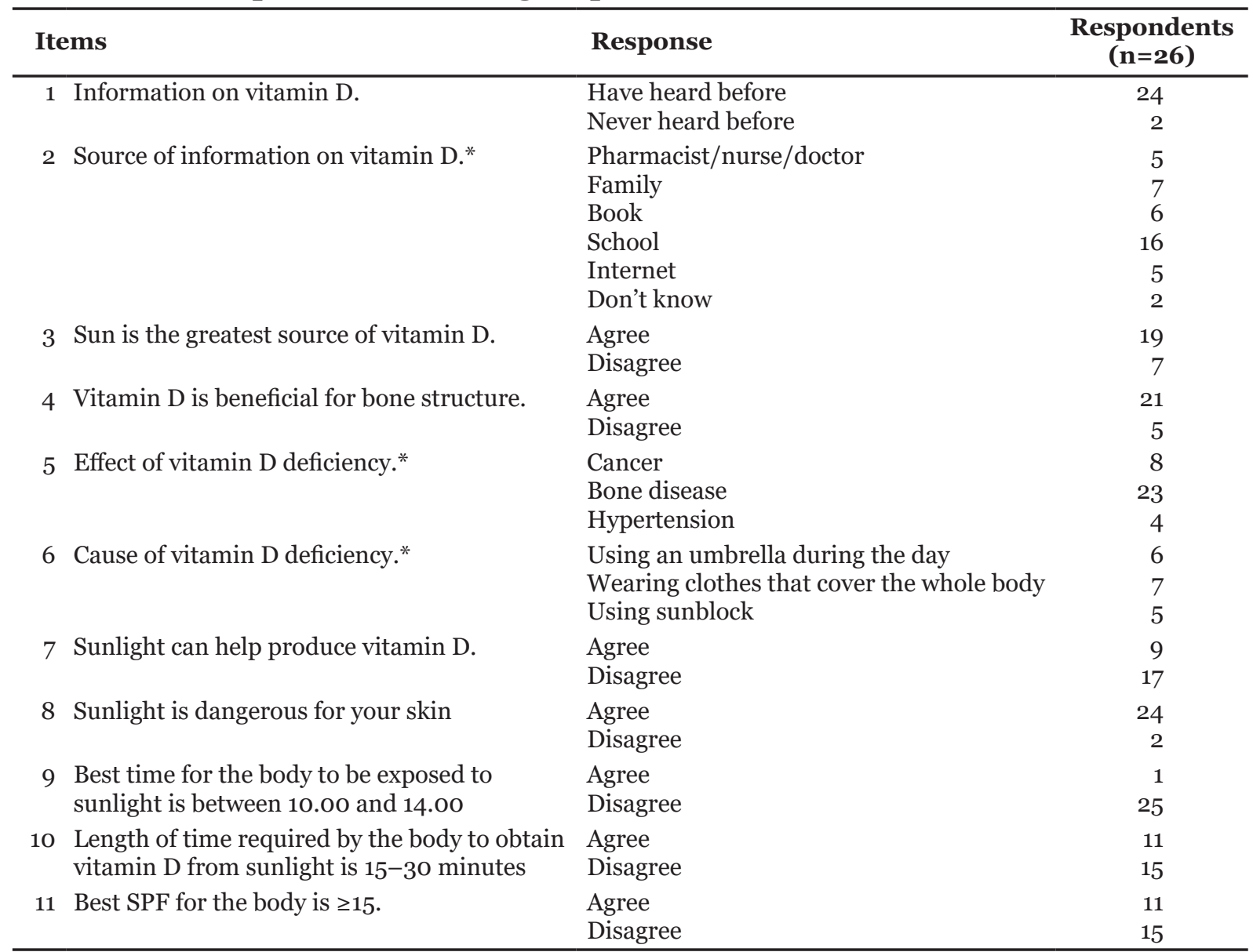

Note: *respondents may choose more than one response 
Table 6 Respondent Attitude towards Sunlight Exposure

\begin{tabular}{|c|c|c|c|}
\hline \multicolumn{2}{|c|}{ Items } & \multirow{2}{*}{$\begin{array}{l}\text { Response } \\
\text { Yes } \\
\text { No }\end{array}$} & \multirow{2}{*}{$\begin{array}{c}\begin{array}{c}\text { Respondents } \\
(\mathbf{n}=\mathbf{2 6})\end{array} \\
16 \\
10\end{array}$} \\
\hline 1 & $\begin{array}{l}\text { Do you often travel or do outdoor activities under } \\
\text { direct sunlight? }\end{array}$ & & \\
\hline 2 & $\begin{array}{l}\text { The amount of time per day you are exposed to } \\
\text { direct sunlight (in minutes). }\end{array}$ & $\begin{array}{l}5 \\
5-15 \\
20-30 \\
>30\end{array}$ & $\begin{array}{r}2 \\
7 \\
6 \\
11\end{array}$ \\
\hline 3 & Do you avoid direct sunlight? & $\begin{array}{l}\text { Yes } \\
\text { No }\end{array}$ & $\begin{array}{r}23 \\
3\end{array}$ \\
\hline 4 & $\begin{array}{l}\text { a. Do you use skin protection to avoid exposure } \\
\text { to direct sunlight? }\end{array}$ & $\begin{array}{l}\text { Yes } \\
\text { No }\end{array}$ & $\begin{array}{r}23 \\
3\end{array}$ \\
\hline & b. The type of skin protection used.* & $\begin{array}{l}\text { Jacket } \\
\text { Sunblock } \\
\text { Jacket and sunblock } \\
\text { No protection }\end{array}$ & $\begin{array}{r}19 \\
4 \\
7 \\
3\end{array}$ \\
\hline 5 & The reason you use skin protection. & $\begin{array}{l}\text { Based on religion } \\
\text { Avoid dark skin } \\
\text { Avoid heat } \\
\text { Easier to apply } \\
\text { Avoid wind } \\
\text { Avoid dark skin and sweat }\end{array}$ & $\begin{array}{r}2 \\
11 \\
6 \\
2 \\
1 \\
1\end{array}$ \\
\hline & No protection. & & 3 \\
\hline 6 & Consuming vitamin D supplements. & $\begin{array}{l}\text { Yes (contain vitamin D) } \\
\text { Yes (does not contain vitamin D) } \\
\text { No }\end{array}$ & $\begin{array}{r}0 \\
10 \\
16\end{array}$ \\
\hline 7 & $\begin{array}{l}\text { The purpose for consuming vitamin D } \\
\text { supplements. }\end{array}$ & & \\
\hline 8 & $\begin{array}{l}\text { The opinion on the needs of vitamin } \mathrm{D} \text { in the } \\
\text { body. }\end{array}$ & $\begin{array}{l}\text { Enough } \\
\text { Not enough }\end{array}$ & $\begin{array}{r}9 \\
17\end{array}$ \\
\hline 9 & Interested in knowing more about vitamin D. & $\begin{array}{l}\text { Yes } \\
\text { No }\end{array}$ & $\begin{array}{r}21 \\
5\end{array}$ \\
\hline
\end{tabular}

Note: *the answer of the respondents may be more than one

because as we get older, vitamin D metabolism will also change, causing a decrease in calcium absorption, intestinal resistance to absorption of calcium to circulation $1,25(\mathrm{OH}) \mathrm{D}$ and reducing vitamin $\mathrm{D}$ production on the skin surface. ${ }^{16} \mathrm{In}$ older people, there is often an increased risk of vitamin $\mathrm{D}$ deficiency due to limited sun exposure and decreased capacity to synthesize vitamin D. ${ }^{17}$ Adults tend to avoid sunlight exposure by using sunscreens and clothing that covers the skin to prevent early aging due to sunlight. ${ }^{18}$ The majority of adults have heard about vitamin D; however, the knowledge regarding the sun as the most significant source of vitamin $\mathrm{D}$ is inadequate so they often use umbrella and sunscreens when exposed to sunlight. ${ }^{19}$

Vitamin D has a relationship with the severity and control of asthma. Adequate levels of vitamin D in the blood have proven effective in the treatment of asthma and can prevent exacerbation of asthma. ${ }^{20}$ Vitamin $\mathrm{D}$ can be produced naturally by the body when exposed to sunlight but excellent knowledge of the danger of light the sun can affect the attitude that tends to avoid sun exposure that respondents who have a history of asthma and avoid sun exposure are at higher risk of experiencing exacerbations due to vitamin D deficiency. ${ }^{21}$

Most respondents experienced vitamin D insufficiency and some had vitamin D deficiency. This is similar to the results delivered by Shebl et al. ${ }^{4}$ stating that asthma patients generally have low vitamin $\mathrm{D}$ level. The link between vitamin $\mathrm{D}$ and asthma patients is still unclear, but vitamin $\mathrm{D}$ has immunomodulatory properties that can reduce the inflammatory process ${ }^{6}$ and has the function of modulating the function of various immune cells. ${ }^{22}$ Vitamin $\mathrm{D}$ is the only vitamin that the 
body can naturally produce when it is exposed to sunlight that the sun can be stated as the primary source of vitamin D. Sunlight ultraviolet B (UVB) radiation converts 7 -dehydrocholesterol in the skin to previtamin D3, which is then converted into active vitamin $\mathrm{D} 3$.

This study has limitations due its limited sample size and non-customary distribution. It also does not consider other factors that can affect vitamin D levels including skin color, weight, residence, and nutritional intake; factors that can influence knowledge such as social factors, economic factors, environmental factors, and experience factors; and factors that can influence attitudes including experience factors, emotional factors, and cultural factors. The measurement of vitamin D level in this study is also still limited because it only used serum vitamin D level without considering vitamin $\mathrm{D}$ intake in the form of nutrients.

\section{Conclusion}

No relationship is found between serum vitamin $\mathrm{D}$ level and level of knowledge and between serum vitamin D level and attitude regarding sunlight exposure for vitamin production. The relationship between knowledge and attitude towards sunlight exposure related to vitamin D is relatively low.

\section{Conflict of Interest}

There is no conflict of interest at all authors.

\section{Acknowledgments}

The authors are grateful to the Faculty of Pharmacy, the University of Surabaya had supported this study, and The Research and Community Service Department (LPPM), University of Surabaya, and the Directorate of Higher Education of Indonesia who has funding for the implementation of this research.

\section{References}

1. World Health Organization. World health rankings. 2014 [cited 2017 September 29]. Available from: http://www. worldlifeexpectancy.com/country-healthprofile/indonesia.

2. Global Initiative for Asthma. Global strategy for asthma management and prevention. 2017 [cited 2017 September 29]. Available from: http://ginasthma.org/2017-gina-reportglobal-strategy-for-asthma-managementand-prevention.

3. Niruban SJ, Alagiakrishnan K, Beach J, Senthilselvan A. Association between vitamin $\mathrm{D}$ and respiratory outcomes in canadian adolescents and adults. J Asthma. 2015;52(7):653-61.

4. Shebl RE, Shehata SM, Elgabry M, Ali SAI, Elsaid HH. Vitamin D and phenotypes of bronchial asthma. Egypt J Chest Dis Tuberc. 2013;62(2):201-5.

5. Albanna EAM, Salah KM, Ahmed HS. Effect of vitamin D and The antimicrobial peptide in asthma. Egypt $J$ Pediatr Allergy Immunol. 2012;10(2):101-7.

6. Bozzetto S, Carraro S, Giordano G, Boner A, Baraldi E. Asthma, allergy, and respiratory infections: the vitamin D hypothesis. Allergy. 2012;67(1):10-7.

7. Elnady HG, Foudac EM, Elsheikha OM, Alameeya IRE, Elshafied AI, Sherifa LS, et al. Serum vitamin D level as predictor of bronchial asthma in Egyptian children. $\mathrm{J}$ Arab Society Med Res. 2013;8(2):67-73.

8. Alemu E, Varnam R. Awareness of vitamin D deficiency among at risk patient. BMC Res Notes. 2012;5:17.

9. Arora H, Dixit V, Srivastava N. Evaluation of knowledge, practices of vitamin $\mathrm{d}$ and attitude toward sunlight among Indian students. Asian J Pharm Clin Res. 2016;9(1):308-13.

10. Hartley M, Lucas R, Hoare S, Lithander F, King L. The sun exposure and vitamin D study. NIWA UV Workshop, Auckland. 2014 [cited 2017 September 29]. Available from: https://www.niwa.co.nz/sites/niwa.co.nz/ files/Hartley_UV\%20Workshop_2014.pdf.

11. Zhou M, Zhuang W, Yuan Y, Li Z, Cai Y. Investigation on vitamin $\mathrm{D}$ knowledge, attitude and practice of University students in Najing, China. Public Health Nutr. 2016;19(1):78-82.

12. Bathi BAA, Zayed KEA, Qenai MA, Makboul G, El-Shazly MKE. Knowledge, attitude and practice of patients attending primary care centers toward vitamin D in Kuwait. Alexandria J Med. 2012;48(3):277-82.

13. Alshahrani F, Aljohani N. Vitamin D: deficiency, sufficiency and toxicity. Nutrients. 2013;5(9):3605-16. 
14. Bonds RS, Horiuti TM. Esterogen effects in allergy and asthma. Curr Opin Allergy Clin Immunol. 2013;13(1):92-9.

15. Lee A, Garbutcheon-Singh KB, Dixit S, Brown $\mathrm{P}$, Smith SD. The influence of age and gender in knowledge, behaviors, and attitudes towards sun protection: a cross-sectional survey of australian outpatient clinic attendees. Am J Clin Dermatol. 2015;16(1):47-54.

16. GallagherJC.Vitamin Dand aging. Endocrinol Metab Clin North Am. 2014;42(2):319-22.

17. Weinstock MA, Tsiaras WG. Factor influencing vitamin D status. Acta Derm Venereol. 2011;91:115-24

18. Bourcher BJ. The Problem of Vitamin D Insufficiency in Older People. Aging Dis. 2012;3(4):313-29.

19. Ho-Pham L, Nguyen M. Survey on knowledge and attitudes on vitamin D and sunlight exposure in an urban population in Vietnam. $\mathrm{J}$ ASEAN Federation Endocrine Societies. 2012;27(2):55-9.

20. Korn S, Hubner M, Jung M, Blettner M, Buhl R. Severe and uncontrolled adult asthma in associated with vitamin D insufficiency and deficiency. Resp Res. 2013;14(25):1-8.

21. Ghamdi KMA, AlAklabi AS, AlQahtani AZ. Knowledge, attitudes and practices of the general public toward sun exposure and protection: a National Survey in Saudi Arabia. Saudi Pharm J. 2016;24(6):652-7.

22. Herr C, Greulich T, Koczulla RA, Meyer S, Zakharkina T, Bransheidt $\mathrm{M}$, dkk. The role of vitamin $\mathrm{D}$ in pulmonary disease COPD, asthma, infection and cancer. Resp Res. 2011;12(31):1-9. 


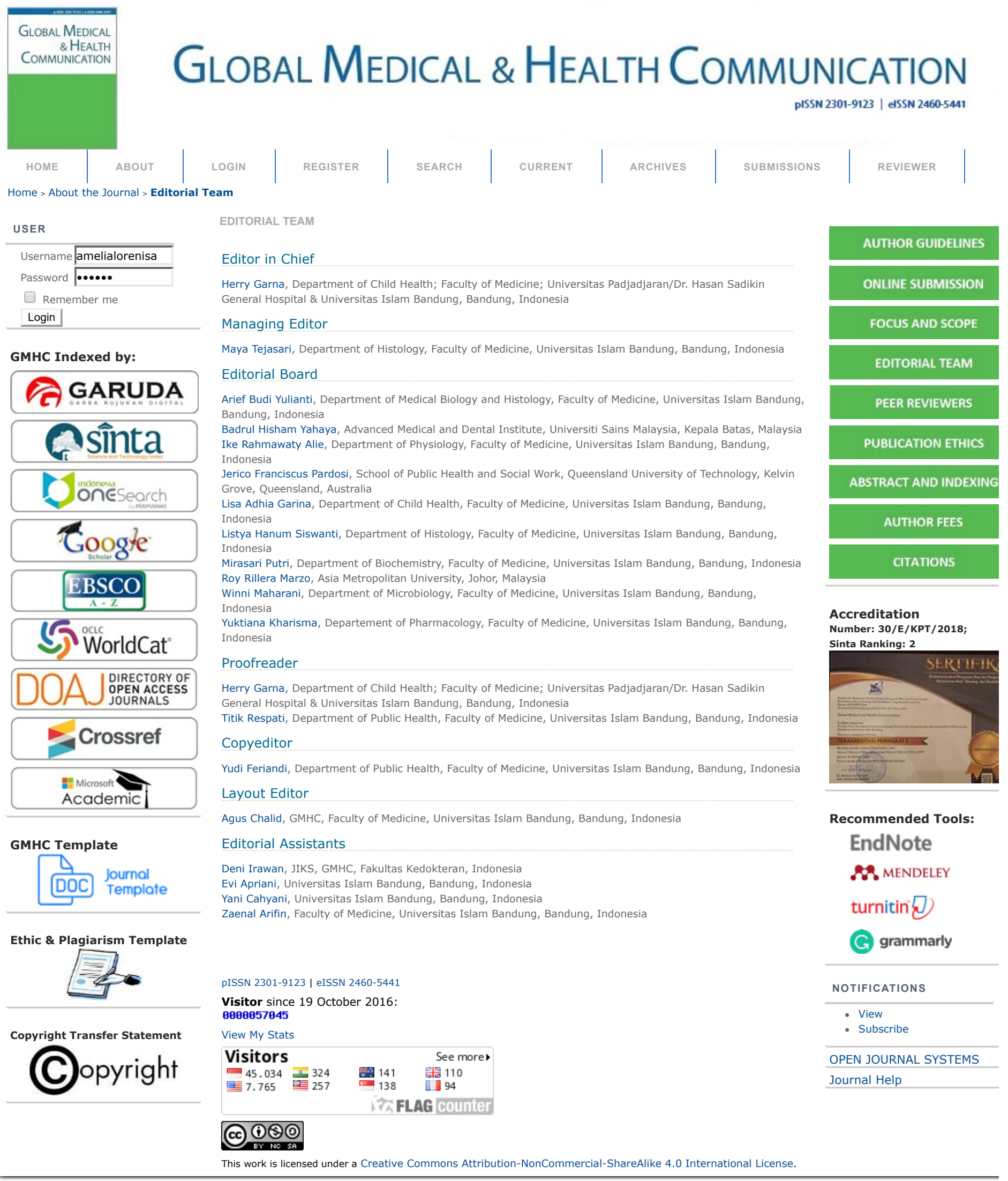




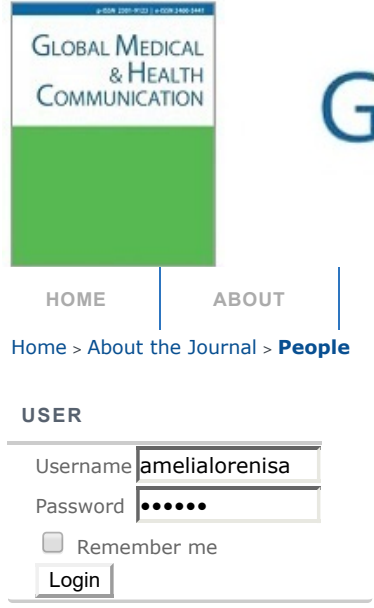

GMHC Indexed by:

C) GARUDA

sînta
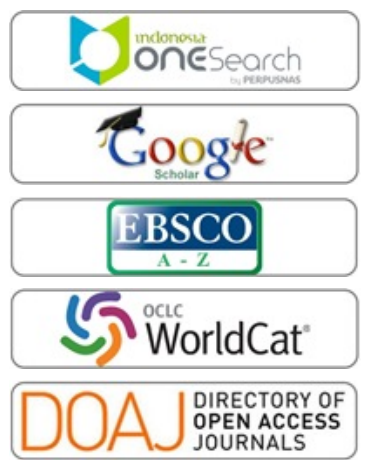

\section{Crossref}

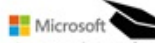

Academic

GMHC Template

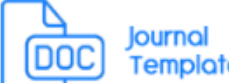

Ethic \& Plagiarism Template

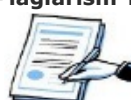

Copyright Transfer Statement

C)opyright

\section{Global Medical \& Health Communication}

pISSN 2301-9123 | elSSN 2460-5441

LOGIN

PEOPLE

Reviewer

Badrul Hisham Yahaya, Advanced Medical and Dental Institute, Universiti Sains Malaysia, Kepala Batas, Malaysia

Budi Setiabudiawan, Department of Child Health, Faculty of Medicine, Universitas Padjadjaran/Dr. Hasan Sadikin General Hospital, Bandung, Indonesia

Chenery Ann E. Lim, Oslo University Hospital, Norway

Cordia Ming Yeuk Chu, Centre for Environment and Population Health, Griffith University, Brisbane, Australia

Ermi Ndoen, UNICEF Indonesia, Jakarta, Indonesia

Ferry Efendi, Faculty of Nursing, Universitas Airlangga, Surabaya, Indonesia

Hendro Sudjono Yuwono, Department of Surgery, Faculty of Medicine, Universitas Padjadjaran-Dr. Hasan Sadikin General Hospital, Bandung, Indonesia

Herri S. Sastramihardja, Department of Pharmacology and Therapy, Universitas Padjadjaran, Bandung, Indonesia

Hidayat Wijayanegara, Department of Obstetrics and Gynecology, Faculty of Medicine, Universitas Padjadjaran, Bandung, Indonesia

Ieva B. Akbar, Department of Physiology, Faculty of Medicine, Universitas Islam Bandung, Bandung, Indonesia

Jerico Franciscus Pardosi, School of Public Health and Social Work, Queensland University of Technology, Kelvin Grove, Queensland, Australia

Lelly Yuniarti, Department of Biochemistry and Molecular Biology, Faculty of Medicine, Universitas Islam Bandung, Bandung, Indonesia

Leri Septiani, RSIA Grha Bunda, Bandung, Indonesia

Lia Faridah, Department of Biomedical Science, Faculty of Medicine, Universitas Padjadjaran, Bandung, Indonesia

M. Ahmad Djojosugito, Department of Orthopedics \& Traumatology, Faculty of Medicine, Universitas Padjadjaran, Bandung, Indonesia

Maya Tejasari, Department of Histology, Faculty of Medicine, Universitas Islam Bandung, Bandung, Indonesia

Mas Rizky Anggun Adipurna Syamsunarno, Department of Biochemistry and Molecular Biology, Faculty of Medicine, Universitas Padjadjaran, Jatinangor, Indonesia

Mirasari Putri, Department of Biochemistry, Faculty of Medicine, Universitas Islam Bandung, Bandung, Indonesia

Niniek Lely Pratiwi, Health Behaviour and Epidemiology, Center of Research and Development for Humaniora and Health Management, National Institute of Health Research and Development (NIHRD), Ministry of Health the Republic of Indonesia, Jakarta, Indonesia

Nunik Kusumawardani, National Institute of Health Research and Development (NIHRD), Ministry of Health the Republic of Indonesia, Jakarta, Indonesia

Nuzirwan Acang, Department of Internal Medicine, Faculty of Medicine, Universitas Islam Bandung, Bandung, Indonesia

Roy Rillera Marzo, Asia Metropolitan University, Johor, Malaysia

Thaufiq S. Boesoirie, Department Ear, Nose and Throat, Faculty of Medicine, Universitas Padjadjaran/Dr. Hasan Sadikin General Hospital, Bandung, Indonesia

Tony S. Djajakusumah, Department of Dermatology and Venereology, Faculty of Medicine, Universitas Islam Bandung, Bandung, Indonesia

Umar Fahmi Achmadi, Department of Environmental Health, Universitas Indonesia, Depok, Indonesia

Wahyu Widowati, Department of Biomolecular, Faculty of Medicine, Universitas Kristen Maranatha, Bandung, Indonesia

Wawang Setiawan Sukarya, Department of Obstetrics and Gynecology, Faculty of Medicine, Universitas Prof. Dr. Hamka, Jakarta, Indonesia

Yani Triyani, Department of Clinical Pathology, Faculty of Medicine, Universitas Islam Bandung, Bandung, Indonesia

Yulia Sofiatin, Division of Epidemiology and Biostatistics, Department of Public Health, Universitas Padjadjaran, Bandung, Indonesia

pISSN 2301-9123 | eISSN 2460-5441

Visitor since 19 October 2016 :

0000057045

View My Stats
AUTHOR GUIDEUNES

ONLINE SUBMISSION

FOCUS AND SCOPE

EDITORIAL TEAM

PEER REVIEWERS

PUBLICATION ETHICS

ABSTRACT AND INDEXING

AUTHOR FEES

CITATIONS

\section{Accreditation}

Number: 30/E/KPT/2018;

Sinta Ranking: 2

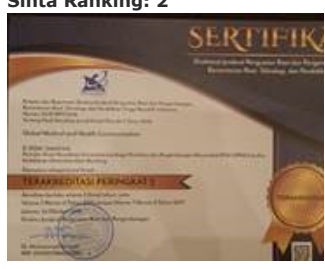

Recommended Tools:

EndNote

8. MENDELEY

turnitin

G grammarly

NOTIFICATIONS

- View

- Subscribe

OPEN JOURNAL SYSTEMS

Journal Help 
Visitors

See more

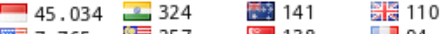

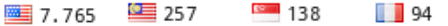

ish FLAG COUnter

\section{(1) $(90$}




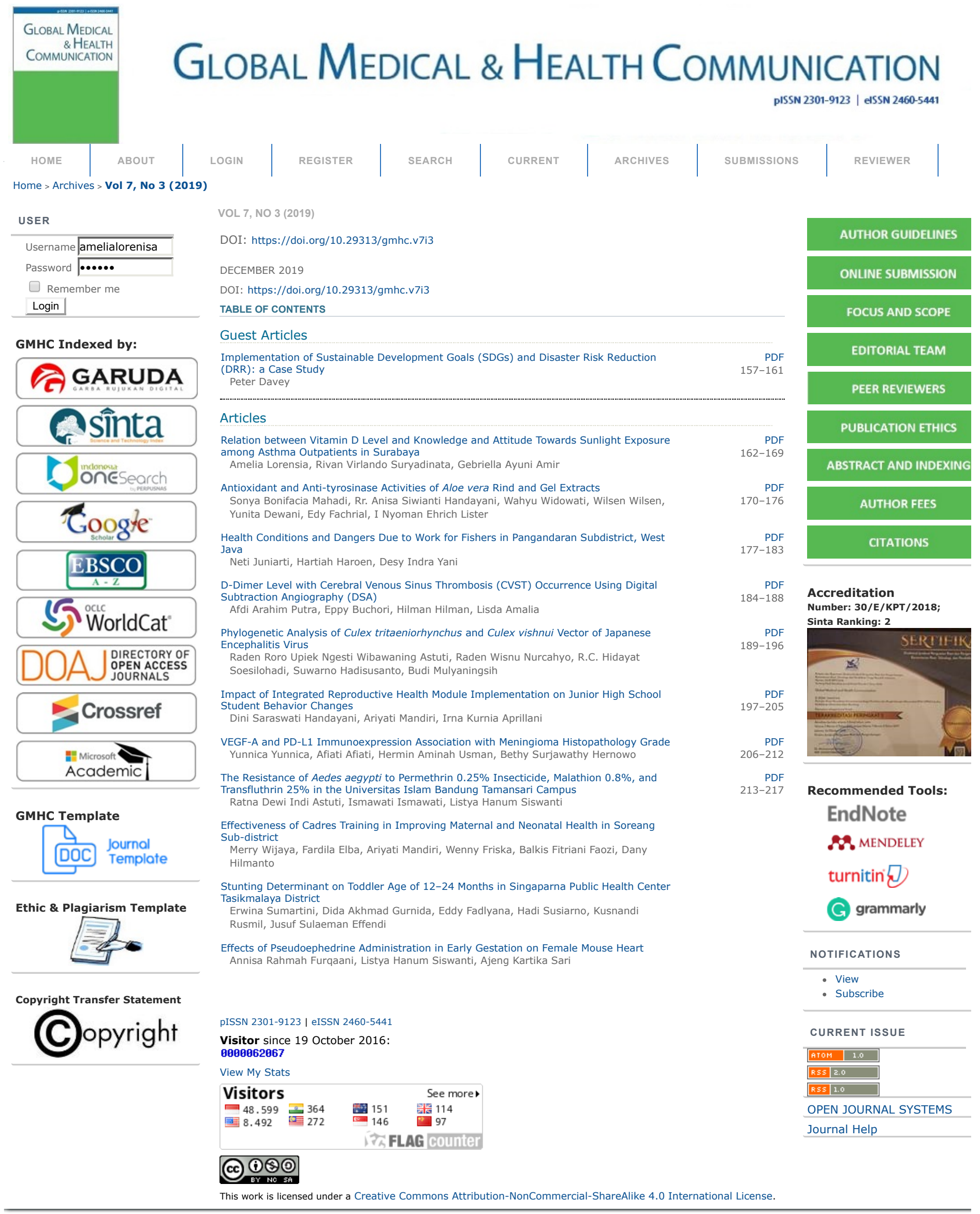

